\title{
ダブルノッチ試験片を用いた高温圧縮層間盖断試験用黒鉛製治具の開発
}

\author{
田邊靖博*, 石井 元, 中西 真, 赤津 隆, 安田榮一
}

(平成14年1月17日受理, 平成14年4月22日採択)

\section{Development of Graphite Jig-Assembly for High Temperature Interlaminar Shear Strength Testing with Double-Notched Specimen Configuration Subjected to Compressive Load}

\begin{abstract}
Yasuhiro Tanabe*, Hajime Ishii, Shin Nakanishi, Takashi Akatsu and Eiichi Yasuda
To measure inter laminar shear strength (ILSS) of C/C composites at high temperatures, a graphite jig was developed on double notched specimen configuration. ILSS of unidirectional C/C composites and 0/90 cross-ply of C/C composites (HTT $2000^{\circ} \mathrm{C}$ and $3000^{\circ} \mathrm{C}$ in both composites) were measured using the assembly up to $1500^{\circ} \mathrm{C}$. In all tests, the shear load showed a liner increase after the initial stage of the loading. The assembly developed was satisfactorily used to measure the ILSS of the C/C composites at high temperatures. All specimens showed catastrophic fracture, and the ILSS largely increased with testing temperature, at least, above $1250^{\circ} \mathrm{C}$. In $\mathrm{C} / \mathrm{C}$ composites, relationships between ILSS and testing temperature seem to depend not on orientation configuration of their reinforcement but on their heattreatment temperature.
\end{abstract}

KEYWORDS : Graphite jig, ILSS, Double notched compression, High temperature, Composite

\section{1.はじめに}

炭素繊維強化炭素複合材料 (C/C複合材料) は, その優れた 特性から高温構造材料としての応用展開が期待され, 研究が 進められている。C/C複合材料は, 繊維軸方向の特性は優れて いるが, 纎維軸以外の方向の特性は必ずしも芳しくない。層 間剪断強度 (ILSS) もその1つである。高温におけるC/C複合 材料のILSSについては, いくつかの報告があるが, $1000^{\circ} \mathrm{C}$ 以 上で一定となる報告1) と測定温度とともに上昇する報告があ

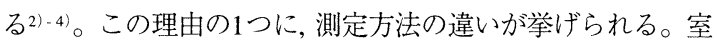
温に扮ける層間剪断強度の測定方法として, Iosipescu法, ダブ ルノッチコンプレッション法 (目違い切り欠き圧縮法：DNC 法), ショートビーム法などが提案されている。試料寸法, 試 料固定法の制約, さらには剪断モードの実現性などを考慮す るとこれら試験法のすべてを高温試験へ適用することは難し (5)。前述の試験法を総合的に判断した結果, DNC法が高温 試験法として有用と考えられた6)。そこで, 高温ILSSの測定 が可能なDNC用治具を新たに設計して, 4 種のC/C複合材料に ついて高温ILSSを測定したので報告する。

\section{2. 実験方法}

\section{1 治具}

先に検討した形状5), 6) の試験片 (2.2項を参照)に合わせて, Fig.1に示す黒鉛 (G540, 東海カーボン) 製の治具を設計した。 圧縮試験時に試験片に曲げ歪が発生するのを抑えるために1 対の試料固定部品 (上側(6), (6)’ と下側(7), (7)) をガイドリング (6), (6)’を(3)で, (7), (7)’を(4)で) で締付け, その間に挿入した 押棒 (上側9)と下側10) を介して荷重を負荷する構造となって いる。試料切り欠き部の開閉をできるだけ抑制するために, Fig.1 (b, d) に示すように試料固定部品は左右で長さが異なっ ている。さらに, Fig.1 (c) に示すようにガイドリングと試料 固定部品には $2^{\circ}$ の勾配をつけ, 試験中にゆるまない構造とし た。加えて, 試験片に平行に圧縮応力か加わるように, 上部台 座は球座付きである。試料に試料固定部品とガイドリングを はめ, 押棒を注意深く挿入して下部台座 (5) に自立させる。 その後, 上部台座をのせて倒れないことを確認して実験を行 つた。試料の破断などで試験片が炉内に散乱しないように， スリーブ (11) をはめて, 試験を行った。

* Corresponding Author, E-mail: y.tanabe@ rlem.titech.ac.jp 東京工業大学応用セラミックス研究所：テ226-8503 横浜市緑区長津田町4259

Materials and Structures Laboratory, Tokyo Institute of Technology : 4259 Nagatsuta, Midori, Yokohama 226-8503, Japan 
(a)
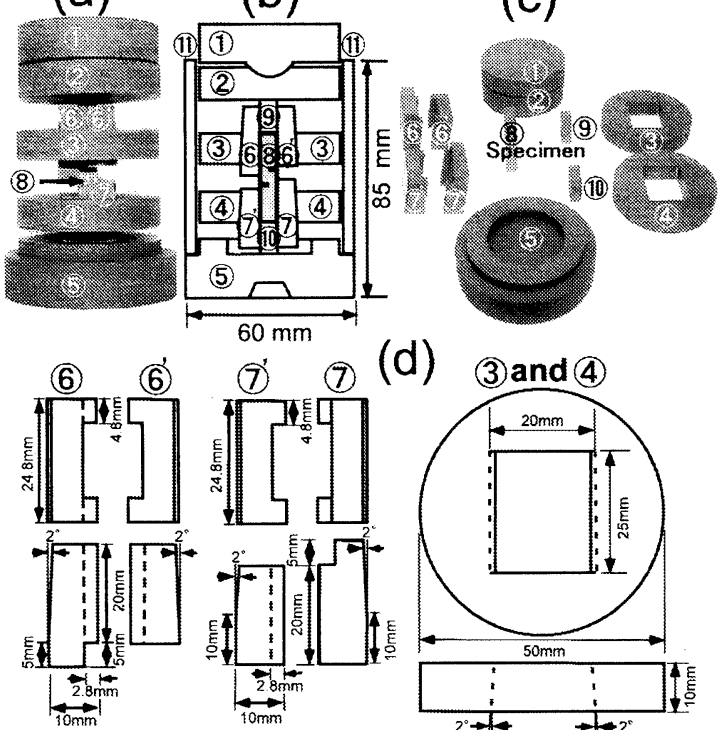

(b)

(c)

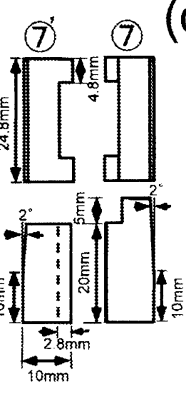

(d)

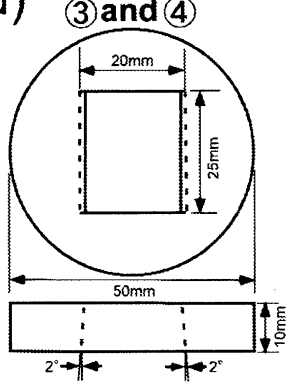

Fig.1 The graphite jig for ILSS at elevated temperatures. (a) Appearance of jig-assembly, (b) the cross-sectional view of the jig-assembly, (c) appearance of the parts, and (d) the plane views of the assembly parts (3), (4), (6), (6)', (7), (7)').

(1) and (2): a set of upper bases with spherical locus, (3) and (4): upper and lower guide rings, (5): bottom base, (6), (6)' and (7), (7)': upper and lower specimen holders acting as a bend protector (8): specimen, (9) and (10): push-bar, (11): guide sleeve.

\section{2 試料ならびに高温試験}

プリフォームドヤーン法で作製した一方向強化 $\mathrm{C} / \mathrm{C}$ 複合材 料ならびに $0^{\circ} / 90^{\circ}$ 直交積層強化C $/ \mathrm{C}$ 複合材料(いずれも(株)ア ロス製エクセルシー：AC200-B10-2000ならびにAC200-B102001 ) を, 不活性雲囲気中 $2000^{\circ} \mathrm{C} ら ひ ゙ に 3000^{\circ} \mathrm{C} て ゙ 30$ 分熱処 理したものを試料として用いた。学振法により求めた各試料 の結晶パラメータをTable 1に示す。熱処理温度の増加とと もに黒鉛化が進んでいる。また,一方向材料よりも直交異方 材料のほうが黒鉛化している。

DNC用試験片寸法はASTM C1292-95aを参考にして, 有限 要素法による応力解析ならびにノッチ巾, ノッチ間隔, 切り込 み深さなどを変えた実験から決定した5).6)。試験片は, $15 \mathrm{~mm}$ 幅, $6 \mathrm{~mm}$ 厚, $30 \mathrm{~mm}$ 長さで, $0.5 \mathrm{~mm}$ 巾で $3.1 \mathrm{~mm}$ 深さの目違い切 り欠きを $15 \mathrm{~mm} \times 30 \mathrm{~mm}$ の両面に各 1 本ずつ, 切り欠き間隔 $6 \mathrm{~mm}$ で入れた ${ }^{6)}$ 。試料を 2.1 項で説明した治具にセットして炉 に設置し, 炉内が所定温度 (室温 $1500^{\circ} \mathrm{C}$ ) に達した後, 15 分 間保持して試験を開始した。Ar雲囲気下, クロスヘッド速度 $0.2 \mathrm{~mm} / \mathrm{min}$ で試験を行った。
Table $1 \mathrm{~d}(002)$ spacing and crystallites size of heat-treated $\mathrm{C} / \mathrm{C}$ composites.

\begin{tabular}{ccccc}
\hline \multirow{2}{*}{$\mathrm{HTT}\left({ }^{\circ} \mathrm{C}\right)$} & \multicolumn{2}{c}{ unidirectional } & \multicolumn{2}{c}{ cross-ply } \\
& $\mathrm{d}(002)(\mathrm{nm})$ & $L \mathrm{c}(\mathrm{nm})$ & $d(002)(\mathrm{nm})$ & $L \mathrm{c}(\mathrm{nm})$ \\
\hline 2,000 & 0.344 & 18.0 & 0.344 & 38.9 \\
3,000 & 0.339 & 28.3 & 0.338 & 74.2 \\
\hline
\end{tabular}

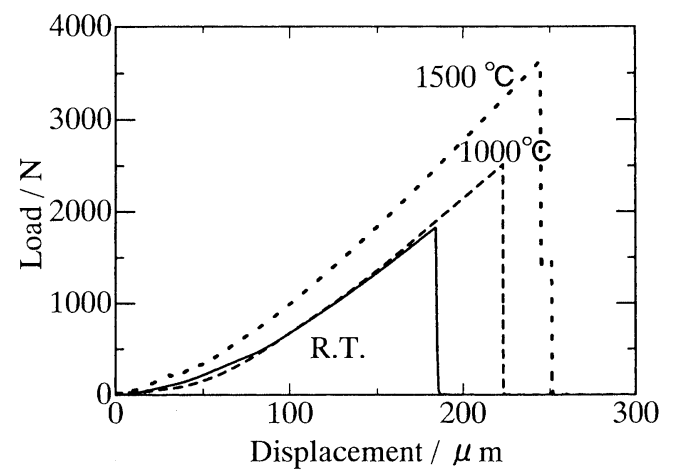

Fig.2 Load-displacement curves for unidirectional C/C composites (heat-treated at $2,000^{\circ} \mathrm{C}$ ) at various testing temperatures.

\section{3. 結果と考察}

Fig.2に設計した治具を用いて測定したILSS測定中の荷重 と変位との関係の一例を $2000^{\circ} \mathrm{C}$ 処理一方向強化C $/ \mathrm{C}$ 複合材料 について示す。負荷初期を除いて, 荷重が線形で増加してい る。この初期部分での非線形は, 押棒 (上側 (9)と下側10) と試 料との微妙な初期アライメントの不一致で発生していると推 察される。ある程度の予荷重を負荷後は, この非線形が小さ くなることを確認している。室温においてスリーブの影響を 確認したが, スリーブの有無で荷重一変位曲線に変化は認め られなかった。本治具を用いて試料に余分な摩擦の影響を与 えずに負荷できていることがわかった。

文献5)に示すSUS製治具を用いて得られたHTT2000 $\mathrm{C}$ 一 方向強化C/C複合材料の室温におけるILSSは $20 \pm 2$ (平均士標 準偏差) MPaであり, 本開発治具を用いて得られた $18 \pm 3$ (平 均土標準偏差) MPaよりもいくぶん高い值を示した。しかし, 標準偏差内に収まっており, 両者には有意差はないと考えら れる。

これらの結果と試料セットが容易であることから, 本治具 は高温におけるILSSを測定する治具として有益であることが わかった。

Fig.3に各試料のILSS 測定值を示す。各温度水隼で5本の試 験片を用いた平均と標準偏差を示してある。各試料ともに, 脆性的な破断を示した。HTT $2000^{\circ} \mathrm{C}$ 一方向強化C/C複合材料

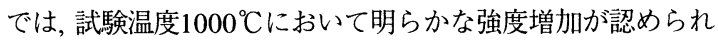




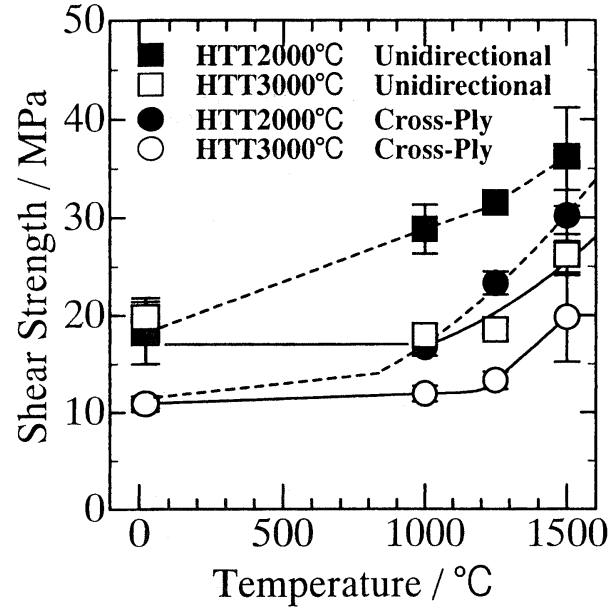

Fig.3 Interlaminar shear strength as a function of testing temperature.

る。また, $\mathrm{HTT} 2000^{\circ} \mathrm{C}$ 直交積層強化 $\mathrm{C} / \mathrm{C}$ 複合材料においても, 試験温度 $1000^{\circ} \mathrm{C}$ で強度の増加が認められる。両試料ともに, これよりも高い試験温度においてさらなる強度増加か認めら れる。これに対して, $\mathrm{HTT} 3000^{\circ} \mathrm{C}$ 一方向強化C/C複合試料で は, 試験温度 $1000^{\circ} \mathrm{C}$ 抢よび $1250^{\circ} \mathrm{C} て ゙ の$ 明確な強度増加は認め られない。しかし, 試験温度 $1500^{\circ} \mathrm{C}$ で明らかに強度が増加し ている。 $\mathrm{HTT} 3000^{\circ} \mathrm{C}$ 直交積層強化C/C複合材料では, 室温よ

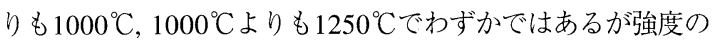
増加が認められ, 試駼温度 $1500^{\circ} \mathrm{C} て ゙ は$ 明らかな強度増加が確 認された。本研究で見る限り, 強度と試験温度との関係は, 強 化繊維の配向形態よりは最終熱処理温度に強く影響されてい ることが伺える。このように試料によって強度と試験温度と の関係は一様ではない。しかし, 今回用いた 4 試料のうち 3 試 料が $1000^{\circ} \mathrm{C}$ を超える試験温度で, すべての試料が $1250^{\circ} \mathrm{C}$ を超 える試験温度で強度増加を示した。これらの結果は, 向後ら”

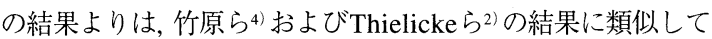
いる。この主因の1つに試験方法の違いが考えられる。ショ 一トビーム法では, 応力状態が複雑》であり, 加えて高温下で は材料の異方性に伴う内部熱応力の変化が加算された影響が 現れたことが考えられる。

破断面を走查型電子顕微鏡 (SEM) で観察した結果, 試験温
度が高いほど, 破面の凹凸が多くなっていた。亀裂の発生あ るいは進展に違いがあることが示唆される。そこで, 各試料 の瀻維軸に垂直な面を室温で平面に研磨し, 高純度窒素雾囲 気中 $1400^{\circ} \mathrm{C}$ までレーザー顕微鏡を用いて観察し, 観察画像を 画像解析して表面の凹凸変化を計測した。その結果, $1400^{\circ} \mathrm{C}$ では繊維のpull-inが観察された。残留応力の解放あるいは強 化繊維のうねりの解放により瀻維のpull-inが生じたと考えら れ, 試験温度の上昇に伴うILSSの増加にこれらの現象が関係 していることが示唆される。

以上より，設計した黒鉛製治具で高温でのILSSを精度良く 測定できることがわかった。本研究の範囲では, 試料の繊維 配向形態あるいはマトリックス組織によらず, $\mathrm{C} / \mathrm{C}$ 複合材料の ILSSは試験温度が高くなると増加した。最終熱処理が強度増 加と試験温度との関係に大きく影響していた。

\section{謝 辞}

本研究の一部は, 文部科学省科学研究費補助金 (No. 10450249）によった。実験に協力をいただいた片野康雄氏に 感謝いたします。高温治具の作製に協力をいただいた応用セ ラミックス研究所研究支援推進員 人見美代志氏, 河島公夫氏 に感謝いたします。

\section{文 献}

1) Y. Kogo, H. Hatta, A. Okura, M. Fujikura and Y. OyaSeimiya, TANSO 1995 [No.166] 40-46 [in Japanese].

2) B. Thielicke, U. Soltesz and H. Unnasch, Proc. ECCMCTS2 1994, Hamburg, Ed., P. J. Hogg, K. Schulte and H. Wittich (1994) pp.325-332.

3) U. Soltesz and B. Thielicke, Proc. Conference on Spacecraft Structures, Materials and Mechanical Testing ESA SP-386, pp.1305-1310, Noordwijk, The Netherlands (1996).

4) M. Takehara, Y. Matsumoto, T. Kingetsu, H. Masumoto and E. Yasuda, TANSO 1996 [No.186] 168-171 [in Japanese].

5) Y. Ishiguro, T. Akatsu, Y. Tanabe and E. Yasuda, CSJ Series 3, TTP, Switzerland (1999) pp.171-174.

6) Y. Ishiguro, T. Akatsu, Y. Tanabe, E. Yasuda, K. Maruyama and S. Yamada, Materials Science and Engineering Serving Society, Ed., S. Somiya, R. P. H. Chang, M. Doyama and R. Roy, Elsevier (1998) pp.285-288.

7) M. Li, R. Matsuyama and M. Sakai, Carbon 1999 [No.37] 1749-1757. 